Rok XIV (2019) | 2 (28) | s. 289-301

https://doi.org/10.12797/LV.14.2019.28.20

Maciej Rak ๑

Uniwersytet Jagielloński, Kraków

maciej.rak@uj.edu.pl

\title{
ZENON KLEMENSIEWICZ \\ A SKŁADNIA DIALEKTÓW \\ POLSKICH I SŁOWIAŃSKICH
}

Słowa klucze: Zenon Klemensiewicz, składnia dialektów polskich, składnia dialektów słowiańskich Keywords: Zenon Klemensiewicz, syntax of Polish dialects, syntax of Slavic dialects

W ocenie dorobku naukowego Zenona Klemensiewicza dialektologia nie jest eksponowana, choć przygotował on prace również z tego zakresu. Bibliografia dialektologii polskiej (BDP) wymienia blisko 20 publikacji tego językoznawcy, które w różnym stopniu sytuują się w zakresie badań gwaroznawczych. Są to (pomijam: dopiski do artykułów innych autorów, biogramy językoznawców, przemowy pogrzebowe i prace, w których informacje o gwarach zajmują zupełnie marginalne miejsce) artykuły dotyczące elementów gwarowych w twórczości Marii Konopnickiej (Klemensiewicz 1970) i Stanisława Wyspiańskiego (Klemensiewicz 1924, 1958), wypowiedzi określające relację gwara - polszczyzna ogólna (Klemensiewicz 1953, 1957) i podręcznik szkolny wraz z informacjami dialektologicznymi (Klemensiewicz 1936). Osobne miejsce zajmują cztery publikacje o składni gwarowej, a dokładniej o wyrazach: co (Klemensiewicz 1938a), $k u$ (Klemensiewicz 1938b), jak (Klemensiewicz 1946) oraz o strukturze zdania (Klemensiewicz 1966).

Celem niniejszego artykułu nie jest charakterystyka lub ocena tych dialektologicznych prac Z. Klemensiewicza, które dotyczą składni (choć w pewnym stopniu mógłby na to wskazywać tytuł), lecz omówienie archiwaliów zgromadzonych w Ar- 
chiwum Nauki PAN i PAU w Krakowie ${ }^{1}$. Ich przegląd przekonuje, że badacz przygotowywał pełną syntezę polskiej składni gwarowej pt. Zarys składni polskich dialektów i brał udział w dyskusji nad tomem syntaktycznym Ogólnosłowiańskiego atlasu językowego (OLA). Jak wiadomo, obydwa projekty do dziś nie zostały zrealizowane. Dialektolodzy skupiają się głównie na słownictwie i fonetyce, w mniejszym stopniu na fleksji i słowotwórstwie, a w marginalnym na składni, gdyż po pierwsze, nie różni się ona za bardzo od składni polszczyzny ogólnej, a po drugie, opis systemowych cech syntaktycznych w gwarach jest trudny ${ }^{2}$. Dokładniej o perspektywach badań w tym zakresie pisała Janina Labocha $(1996,2018)$, zwracając uwagę na to, że nie da się opisać składni gwar bez kontekstu pragmalingwistycznego i socjolingwistycznego. Z kolei w OLA dotychczas omówiono właściwości fonetyczno-gramatyczne (6 tomów) i leksykalno-słowotwórcze (8 tomów). W kwestionariuszu wydanym do tego atlasu (Voprosnik: 68-73) zjawiska syntaktyczne zostały ujęte w następujące punkty: składnia przypadków (dopełniacz, narzędnik, przypadki wywoływane wyrazem między, przypadki wywoływane wyrazem po), konstrukcje składniowe, predykat nominalny, składnia czasowników być i mieć, czasowniki modalne, konstrukcje z bezokolicznikiem, konstrukcje z imiesłowem, składnia zdań: oznajmującego, pytajnego, bezpodmiotowego, związki składniowe wyrazów, zdanie podrzędnie złożone, partykuły.

W zbiorach Archiwum Nauki PAN i PAU w Krakowie pod sygnaturą K III-27 w teczkach składających się na spuściznę po Klemensiewiczu zostały umieszczone: 1) czarny zeszyt formatu $17 \times 21 \mathrm{~cm}$, zawierający $3,5 \mathrm{~cm} \mathrm{~b}$. kartek, na jego okładce znajduje się napis Mat[eriały] warszt[atowe]. Mat[eriały] do składni dialektów (jedn. 38); 2) maszynopis artykułu Jaroslava Bauera ${ }^{3}$. Zjawiska składniowe w „Atlasie językowym ogólnosłowiańskim" (jest to streszczenie artykułu Otázka syntaktických jevư $v$ slovanském jazykovém atlase (Bauer 1959)) wraz z krytycznymi uwagami Klemensiewicza na 14 kartkach formatu A4 (jedn. 11/6). Przyjrzyjmy się dokładniej obydwu archiwaliom.

1 Za udostępnienie zbiorów bardzo dziękuję dr. Adamowi Górskiemu, dyrektorowi Archiwum Nauki PAN i PAU w Krakowie.

2 Nie znaczy to jednak, że dialektolodzy zupełnie zaniedbują składnię gwarową - w BDP mamy osobny dział Składnia. Warto nadmienić, że w tym zestawieniu, co zrozumiałe, zostały ujęte tylko publikacje. Nie znajdziemy tu więc np. wykazu prac magisterskich, a takie z zakresu składni dialektów powstawały pod kierunkiem Zenona Klemensiewicza, np. w 1954 r. Jadwiga Konieczna (później Konieczna-Twardzikowa) obroniła rozprawę pt. Ogólna charakterystyka związków i szeregów $w$ zdaniu $w$ gwarach $w$ zestawieniu $z$ ich zasobem $w$ polskim języku literackim (Kałkowska 2010: 49).

3 Jaroslav Bauer (1924-1969) - czeski syntaktolog, badacz składni słowiańskiej, zwłaszcza spójników i zdania, profesor Uniwersytetu Jana Evangelisty Purkynego w Brnie (dziś Uniwersytet Masaryka). 


\section{Zarys składni polskich dialektów Z. Klemensiewicza}

Wykaz zagadnień składniowych, które miały zostać uwzględnione w Zarysie składni polskich dialektów, Klemensiewicz poprzedził roboczym wstępem:

\section{Zarys składni polskich dialektów}

1) wypowiedzenie;

2) złożenia wypowiedzeniowe.

Na plan pojęcia przyjdzie czas później. Wywodzi mi to dwie możliwości.

a) albo w oparciu o moją składnię polszczyzny kulturalnej [Klemensiewicz 1937 M.R.] dać pełny obraz składni dialektów, a więc dla każdej kategorii wymienionej w składni kult[uralnej] pol[szczyzny] dawać odpowiednik dialektyczny ze szczególnym oczywiście uwzględnieniem rzeczy osobliwych;

b) albo też ograniczyć się wyłącznie do osobliwości, odrębności, a więc dać tylko to, co jest inne, nie w dial[ekcie] kult[uralnym].

$\mathrm{W}$ tej chwili zdaje mi się, że pierwsza alternatywa jest lepsza.

W [takim] razie jednakże trzeba opracować materiał, który był zbierany raczej pod kątem widzenia osobliwości. Po zebraniu materiału można się zorientować, jak postąpić odnośnie kompozycyi.

1. Każda osobliwość dostanie swój arkusz, na razie będzie się pisać numery kartek.

2. Po wyczerpaniu całości, można na tle arkusza poprowadzić przeróżne studia.

(Kreska oznacza koniec gwary).

Na końcu zeszytu znajduje się też dodatkowa kartka, por.:

Wybrane zagadnienia składni dialektów polskich

6. bez // przez

1.00

7. imiesłowowe zwroty

2. jak (O syntaktycznych funkcjach wyrazu jak w dialektach ludowych)

$4 . \mathrm{ktt}$

8. zgoda

3. przyczynowy stosunek zespolenia

5. wnioskowy stosunek zespolenia 


\section{9. luźne grupy}

10. ogólna charakterystyka wypowiedzeń.

Jak widać, Klemensiewicz w pierwszej kolejności zajął się osobliwościami składni gwarowej. Punkty, które omówił w postaci artykułów, wykreślił z tego spisu. Jak wyglądały przygotowania pozostałych tematów, nie wiadomo.

Na luźnych kartach badacz umieścił odesłania do następujących zagadnień syntaktycznych: aby, albo, aż, ba, bez, biernik czasu, biernik z bezokolicznikiem, co ('ile'), co ('który'), co ('że'), coby ('żeby'), doma, gdy, gdyby, gdyż, gwoli, iz, iżby, jak ('czasowe'), jak ('w różnych formach'), jednak, jeno, jeśli, jeżeli, kiedy, koło, ku, liczebnik, liczebników składnia, nale, orzecznik, osobowe zwroty, pluralis poważania, po, przytoczenia w splocie, składnia mowy niezależnej/zależnej, spójniki czasowe, spójniki wynikowe, szyk, zaimki powiązania, zaimki okolicznikowe, zaimki czasu, zaimki miejsca, zaimki przyczyny, zaimki w funkcji, zaś parataktyczne, zgoda, złożenia z oznajmieniem imiestowowym.

Każde z wymienionych zagadnień znajduje się na osobnej kartce (jest ich 48), na której poza nagłówkiem (czyli hasłem składniowym) mamy cyfry oraz skróty: Śl, Mp, Wp, M, MCh, K i KW (por. fot. 1). Oznaczają one odpowiednio dialekty: śląski, małopolski, wielkopolski, mazowiecki, mieszane mazowiecko-chełmińskie, kaszubski oraz kresowe. Ta kolejność nie jest przypadkowa, odpowiada kolejności tekstów w Wyborze polskich tekstów gwarowych Kazimierza Nitscha (1929) i wskazuje, że Zarys... miał być oparty na materiale z tego właśnie zbioru, z wydania z 1929 r. Cyfry to oczywiście numery stron Wyboru..., na których znajduje się dana cecha składniowa. Jeśli idzie o pisownię cytatów, to - jak przekonują przykłady umieszczone w trzech artykułach opracowanych na podstawie tego materiału (Klemensiewicz 1938a, 1938b, 1946) - Klemensiewicz w Zarysie... miał prawdopodobnie zastosować ujednolicony zapis półfonetyczny (jak wiadomo, $\mathrm{w}$ Wyborze... zapis poszczególnych tekstów jest różny).

Ustalenie podstawy materiałowej wskazuje na chronologię tego rękopisu. Klemensiewicz zajął się tematem składni gwarowej po 1929 r., a przed 1938, wtedy bowiem wyszły przywoływane już wyżej artykuły o wyrazach co i $k u$.

Poza kartkami z rozpisanymi zagadnieniami syntaktycznymi w teczce o numerze 37 mamy:

1) 261 kartek o formacie $10 \mathrm{x} 15 \mathrm{~cm}$. Każda $\mathrm{z}$ nich jest ponumerowana i odnosi się do materiału składniowego, który znajduje się na kolejnych stronach Wyboru... (numer kartki odpowiada numerowi strony). Prawdopodobnie Klemensiewicz, czytając Wybór..., w pierwszej kolejności wypisał zjawiska syntaktyczne, a następnie na tak przygotowanej bazie opracował fiszki z poszczególnymi zagadnieniami (por. fot. 2). 


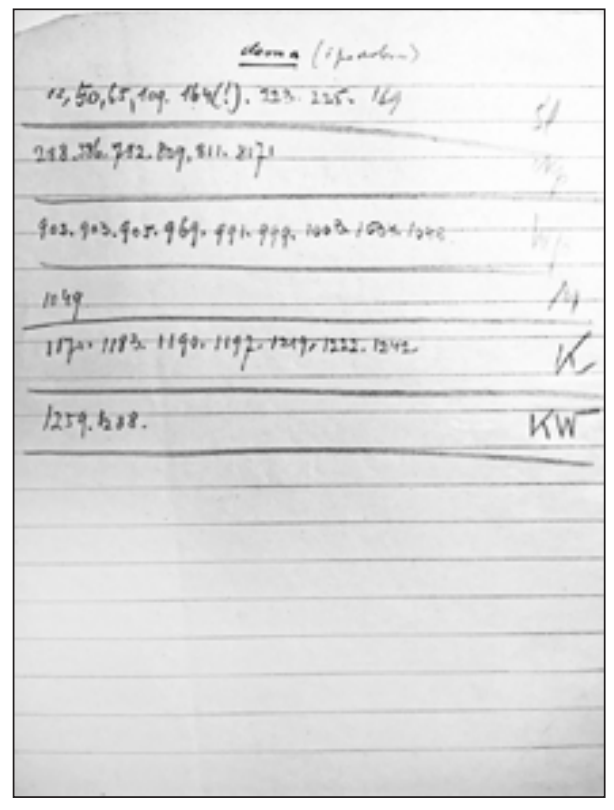

Fot. 1

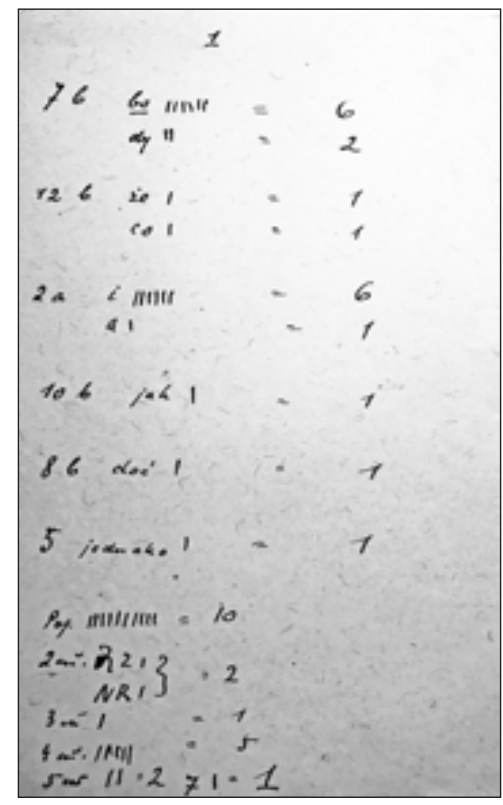

Fot. 2

2) 15 ponumerowanych kartek z zestawieniami liczbowymi i procentowymi dotyczącymi (podaję oryginalną terminologię) stosunków zespolenia różnego typu: celowego, czasowego, odróżniającego, porównawczego, przeciwstawnego, przestrzennego, przyczynowego, przywalającego, skutkowego, warunkowego, wnioskowego i wyjaśniającego. Osobne kartki dotyczą: przytoczeń w splocie, luźnych grup i złożeń $\mathrm{z}$ oznajmieniem imiesłowowym. Zestawienia procentowane i liczbowe miały z pewnością ujawnić tendencje obecne w składni gwarowej i jej różnice w porównaniu ze składnią polszczyzny literackiej (por. fot. 3).

3) schemat budowy zdań gwarowych w ujęciu liczbowym i procentowym (por. fot. 4).

Jak wynika z tego zestawienia, Zarys... miał ujmować składnię gwarową z dwóch perspektyw: formalnej i funkcjonalnej, a także opisywać strukturę zdania. Druga wojna światowa zatrzymała jednak prace Klemensiewicza nad tym tematem (zajął się on wtedy Historia języka polskiego (Klemensiewicz 1961, 1965, 1972)), a później pojawiły się nowe perspektywy i metody, które sprawiły, że przygotowywana monografia straciła na aktualności i pozostała jako nieukończony rękopis. 


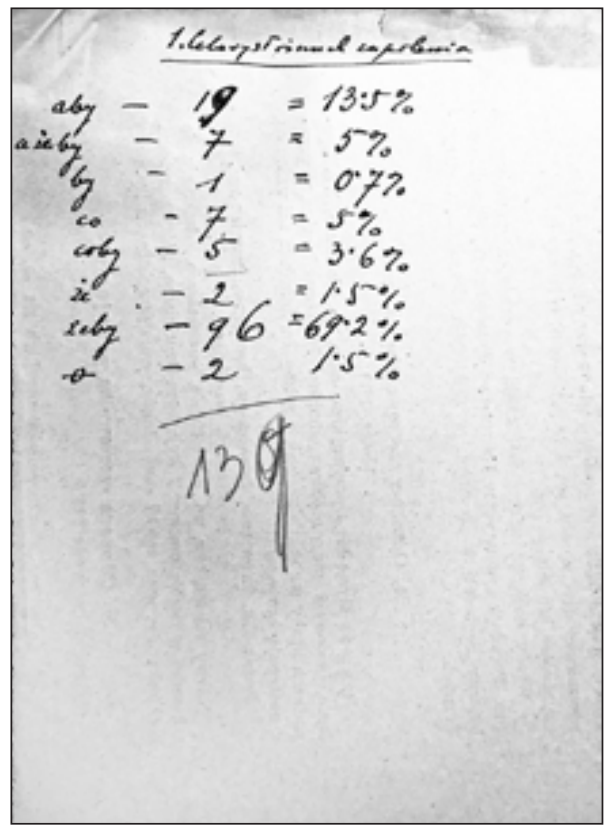

Fot. 3

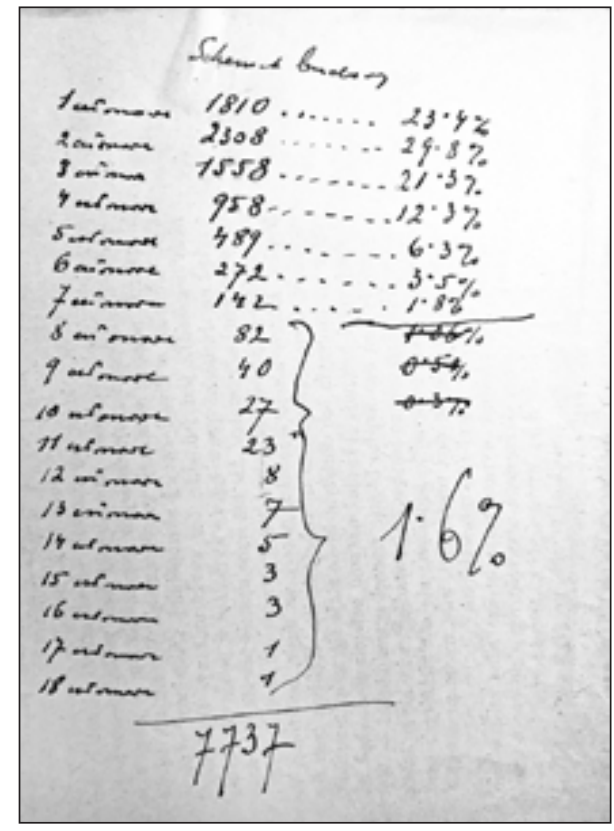

Fot. 4

Od lat 50. zeszłego wieku materiały do składni gwarowej gromadzono także w ośrodku warszawskim, i to w inny sposób, niż robił to początkowo Klemensiewicz. Wpływ na to miała m.in. warszawska międzynarodowa konferencja słowiańskich dialektologów z listopada 1959 r., podczas której dyskutowano nad OLA (Urbańczyk 1959). Jak wiadomo, początki tego atlasu sięgają 1958 r., gdy na IV Międzynarodowym Zjeździe Slawistów w Moskwie zdecydowano o rozpoczęciu prac kartograficznych. W artykule O projekcie „Ogólnosłowiańskiego atlasu dialektologicznego” Zdzisław Stieber (1958) przypomniał, że właściwie pierwszy raz ten pomysł zgłoszono w 1934 r. na II Zjeździe Filologów Słowiańskich w Warszawie. Jeśli idzie o składnię, w Moskwie bardzo nieprecyzyjnie określono, że w OLA nie może zabraknąć działu syntaktycznego. Jak miał wyglądać? Czego dokładnie miał dotyczyć? Tego wówczas nie określono. Do tematu wrócili uczestnicy wspomnianej warszawskiej konferencji z 25-28 XI 1959 r., w tym Z. Klemensiewicz. Jak czytamy w sprawozdaniu:

Do bardzo spornych spraw należało objęcie atlasem składni. Wyrażono poważne wątpliwości, czy można ułożyć kwestionariusz takich zagadnień, które, nie będąc $\mathrm{w}$ istocie leksykalnymi (jak spójniki), nadawałyby się do zbierania metodą ankietową, a przy tym nie należały raczej do stylistyki językowej niż do składni. Ostatecznie jednak postanowiono z prób z góry nie rezygnować. Szczególnie językoznawcy czechosłowaccy gorąco występowali w obronie składni, oni też obok Polaków podjęli się sporządzenia próbnego kwestionariusza i próbnych badań terenowych dla opracowania właściwej metody zdobywania odpowiedzi (Urbańczyk 1959: 391-392). 
Pod wpływem tych dyskusji i deklaracji pod kierownictwem i przy czynnym udziale Haliny Konecznej (por. Judycka, Lewicki, Iwanowa-Perczyńska 1961) powstał polski próbny kwestionariusz syntaktologiczny, w którym uwzględniono następujące zagadnienia: 1) zdanie jednoczłonowe werbalne (21 pytań), 2) zdanie jednoczłonowe nominalne (11 pytań), 3) orzeczenie, w którego skład wchodzą bezokolicznik i imiesłów (35 pytań), 4) zdanie egzystencjonalne (10 pytań), 5) grupa podmiotu i orzeczenia (13 pytań), 6) stopniowanie: wzmacnianie i osłabianie różnych części mowy (6 pytań), 7) przydawka (19 pytań), 8) partykuły (3o pytań), 9) przyimki (Perczyńska 1962: 404).

Od lat 30. XX w. widać było wyraźną ewolucję zarówno w podejściu do materiału składniowego, jak i w stosowanej metodzie. O ile Zarys... był oparty na tekstach opublikowanych przez Nitscha, o tyle Koneczna zbierała materiał w terenie za pomocą kwestionariusza. Klemensiewicz zdawał sobie sprawę z tego, że teksty Nitscha nie dają w pełni wiarygodnego obrazu składni, były bowiem dostarczane przez różne osoby, nieprzygotowane i niewyczulone na sprawy syntaktyczne. $\mathrm{W}$ konsekwencji w Wyborze... dominują monologi o charakterze opisowo-sprawozdawczym w czasie przeszłym. Ostatni z cyklu artykułów dotyczących składni dialektalnej badacz oparł więc na trzech pierwszych tomach Polskich tekstów gwarowych $z$ ilustracją dźwiękowa Zenona Sobierajskiego (1960-1964), które w odróżnieniu od zbioru Nitscha zawierają znacznie więcej przykładów składni mowy potocznej swobodnej: „jest [ona] rezultatem operacji doraźnej, zwłaszcza w żywym tempie dialogu, co obniża poziom staranności i ogranicza udział krytycznej, refleksyjnej kontroli samego siebie w wykonywaniu szczegółów budowy składniowej" (Klemensiewicz 1966: 245). W odniesieniu do wcześniejszych materiałów dialektologicznych Klemensiewicz wypowiedział się w następujący sposób:

Zapisywanie ręczne pełnych wypowiedzi z całą ich obudową prozodyczną jest niemożliwe. Nie można też ponowić obserwacji nad jakimś interesującym zdaniem, ponieważ ono jest wytworem spontanicznego, niepowtarzalnego aktu językowej działalności (ibid.).

Powyższy cytat może być też traktowany jako głos w dyskusji nad przydatnością tekstów gwarowych w badaniach składniowych i nad sposobami gromadzenia materiału. Ingerencja w opracowywane teksty, polegająca np. na usuwaniu powtórzeń, poprawianiu anakolutów itd., sprawia, że zapisany fragment jest przydatny zwłaszcza dla badacza leksyki, z kolei syntaktolog niewiele z niego skorzysta. Na ten temat, a także o wykorzystaniu tekstów folkloru w badaniach składni pisał już Stanisław Urbańczyk (1938), komentując dwa artykuły Klemensiewicza (1938a, 1938b). 


\section{Polemika Zenona Klemensiewicza z Jaroslavem Bauerem}

Na warszawską konferencję przyjechał również J. Bauer. W 1959 r. opublikował artykuł o tym, jak mogłoby wyglądać ujęcie zagadnień składniowych w OLA oraz o zjawiskach syntaktycznych, które można gromadzić za pomocą kwestionariusza (Bauer 1959). Tekst ten przetłumaczono na język polski, by w Warszawie ułatwić dyskusję nad poruszanymi w nim tematami. Klemensiewicz w 1960 r. (na marginesie pierwszej karty ołówkiem została podana ta właśnie data) podjął polemikę z propozycją Bauera, której dowodem jest 14 zapisanych ręcznie kartek z uwagami do poszczególnych części artykułu Zjawiska składniowe w „Atlasie językowym ogólnosłowiańskim" (sygn. K III-27).

Jako zjawiska zupełnie nienadające się do badań, a zaproponowane przez Bauera Klemensiewicz uznał:

1. Oboczność partykuł pytających $c z y$, li połączonych z odpowiednią intonacją, np. czy przyjedziesz?

2. Oboczności typu: co robić? / co by tu robić? / co mamy robić?

3. Oboczność spójników rozłącznych czy/albo.

4. Oboczność zaimków przysłówkowych pytających czemu/dlaczego.

5. Oboczność konstrukcji z funkcją żądającą typu chodźmy!/idziemy!

6. Konstrukcje z to z funkcją ekspresywną typu: ale to grzmi! to leje! to cymbał!

7. Zaimek ten w funkcji rodzajnika, zaimek taki w funkcji dodatkowych wykładników stopnia, miary, ilości wywołujący zdziwienie, zachwyt, oburzenie, np. to jest takie drogie!

8. Lokalizacja nie, które razem z zaprzeczonym wyrazem zajmuje dane miejsce w zależności od zamiaru komunikacyjnego.

9. Oboczność konstrukcji typu: wojny nie będzie / wojna nie będzie.

10. Oboczność leksykalna wykładnika zgody lub sprzeciwu, np. tak, ano, jo, da.

11. Oboczność wyrazów modalnych typu musi, pono.

12. Obecność łącznika lub jego brak w orzeczeniu złożonym.

13. Zbadanie podstawowych typów anakolutów, gdyż wiele z tych zjawisk ma charakter indywidualno-stylistyczny i okazjonalny.

14. Zagadnienie wykolejania konstrukcji z wysuniętym członem zdania, typu: A Piotr, jemu już dawno o tym mówiłem.

15. Różnica szyku wyrazów.

Z kolei do zjawisk syntaktycznych nadających się do zbadania Klemensiewicz zaliczył:

1. Oboczność pada / ono pada, w której drugi człon - według Klemensiewicza - jest postacią pamiątkową rozwojową, a nie - jak podaje Bauer - postacią z zabarwieniem emocjonalnym.

2. Oboczność typu: była moc ludzi / było moc ludzi / był moc ludzi, przyszedł szereg ludzi / przyszło szereg ludzi, czyli proces adwerbializacji rzeczownika i jego następstwo w składni zgody. 
3. Oboczność żaden/nikt.

4. Typ: było zabrónowano = zabronowali/zabronowano, śmietana była zebrana łyz$k a=$ zebrana / zebrali tyżką śmietanę.

5. Da, dało z biernikiem w znaczeniu 'jeść', np. dało kawe = była kawa = er gab Kaffee.

6. Przydawka typu: pień od brzozy, syn od siostry = pień brzozy, syn siostry.

7. Typ: cieszyć się, radować się, uśmiechać się komuś.

8. Konstrukcja $\mathrm{z}$ dopełnieniem: jest mi dziesięć lat.

9. Wyrażenie $\mathrm{z} k u \mathrm{z}$ celownikiem $=$ ogpol. do $\mathrm{z}$ dopełniaczem $\mathrm{w}$ funkcji dopełnienia lub okolicznika.

10. Dopełniacz dopełnienia cząstkowego.

11. Na z dopełniaczem = dla z dopełniaczem, np. mam na każdego 'mam dla każdego'.

12. Podwojony przyimek w wyrażeniu przyimkowym z przydawką, np. na matkę, na swoją.

13. Typ: zrobiony od kogoś.

14. Typ: widzieć kogoś leżeć.

15. Typ: jażem go widział, stojąc = 'widziałem go stojącego'.

16. Typ: bez most przez czapki, bez zime itp.

17. Typ: $z e / z+$ dopełniacz.

18. Typ: lecie, zimie, poście.

19. Typ: łoński rok, tj. biernik 'tamtego roku albo w tamtym roku'.

2o. Przyimki: $o, w$, na z biernikiem w funkcji okolicznika czasu.

21. Typ porównania: Farba jest gorso brudzonco = 'bardziej'.

22. Wyraz ba jako wskaźnik zespolenia składnika przeciwstawnego.

23. Przyimki: kole / kołá / kele; pole / poło / pele / podle / pu; wele / wedle / wela / welá / wiele.

Do zagadnień warunkowo nadających się do zbadania według Klemensiewicza należały:

1. Partykuły pytające i rozłączne, np. li, czy, ali.

2. Konstrukcja przeczenia jedno- i wielokrotna.

3. Konstrukcja $\mathrm{z}$ dopełniaczem po zaprzeczonym czasowniku przechodnim.

4. Rejestr czasowników w zdaniu bezpodmiotowym oraz opis ich składni z dopełnieniem, typ: pachnie sianem, rzuciło nim.

5. Rejestr konstrukcji z orzeczeniem w 3. osobie lp., związanym z podmiotem, który nie jest wyrażony, typ: mówi się, mówią, nie kupi (= 'nie kupi się').

6. Rejestr czasowników, przy których występuje podmiot w dopełniaczu cząstkowym. Na obszarze polskim nie ma zróżnicowania w tym względzie.

7. Konstrukcje mianownika i narzędnika w funkcji orzeczenia imiennego. Odchylenia od normy tłumaczy się albo pozycją, np. Głupia ta kobieta nie jest, albo nacechowaniem stylistycznym.

8. Zjawiska zgody podmiotu i orzeczenia. Czy jest jakieś regionalne zróżnicowanie, a jeśli go nie ma, to jaki typ panuje? 
9. Zagadnienie „konkurencji”, czyli potencjalnej przydawki przymiotnej i dopełniaczowej, to raczej problem stylistyczny.

10. Oboczność typu: język polski i czeski / języki polski i czeski.

11. Miejsce przydawki rzeczownej przed nadrzędnikiem albo po nim.

12. Potencjalna przydatność konstrukcji obocznych typu: siwowłosy starzec / starzec o siwych włosach.

13. Konstrukcje typu: kupił maki, pożycz mi noża.

14. Bezokolicznik w funkcji dopełnienia i okolicznika; wymienność konstrukcji bezokolicznikowej z wypowiedzeniami pobocznymi.

15. Użycie atrybutu predykatywnego, miara jego adwerbializacji i jego zastępowanie różnymi konstrukcjami charakteru okolicznikowego.

16. Żywotność i warunki użycia zwrotów imiesłowowych, ich funkcje syntaktyczne oraz stosunki znaczeniowe do orzeczenia.

17. Resztki mianownika w funkcji okolicznika miejsca i czasu.

18. Resztki miejscownika w okolicznikach czasu, typ: ziemie, lecie.

Ostatnią grupę stanowią zagadnienia według Klemensiewicza niejasne i wątpliwe, por.:

1. Nie ma polskich konstrukcji, które by odpowiadały czeskiej oboczności: $v$ komíne to huči / v komínĕ hučí, a jest w języku polskim konstrukcja nie idzie mi to, ale w niej to nie odnosi się do czegoś nieokreślonego.

2. Użycie podmiotu zaimkowego - nie jest jasne, co ta propozycja znaczy.

3. Jak się wyraża znaczenie istnienia i posiadania przez czasowniki: być, mieć, to sprawa klasyfikacji semantycznej.

4. Przedstawienie różnych typów biernego orzeczenia.

5. Rozróżnienie albo nierozróżnienie okolicznika miejsca odpowiadającego na pytania: gdzie i dokąd.

6. Formy i funkcje przysłówków sposobu.

7. Problematyka ilustrowana powierzchownym wyborem przykładów przedstawiona w rozdziale II artykułu Bauera nie nadaje się do dyskusji.

Jak się okazało, ani artykuł J. Bauera (1959), ani polemika Z. Klemensiewicza z wyłożonymi w tym tekście propozycjami nie zostały w odpowiedni sposób uwzględnione w OLA (inna sprawa, że polemika pozostała w rękopisie i dlatego nie była szerzej znana). W Voprosniku... - jak już o tym pisałem wyżej - wyszczególniono tylko część zjawisk syntaktycznych (zresztą sformułowanych ogólnie), które miały być gromadzone niejako przy okazji zbierania informacji leksykalnych i fonetycznych.

Dorobek syntaktologiczny Klemensiewicza pozwala wnioskować, że jego zainteresowanie składnią gwar polskich być może było związane tak naprawdę z pró- 
bą ujęcia składni polszczyzny mówionej. W książce Składnia opisowa współczesnej polszczyzny kulturalnej (Klemensiewicz 1937) przedmiotem opisu był język pisany, nie dysponowano bowiem wtedy korpusami tekstów mówionych, trzeba było na nie poczekać jeszcze ponad 40 lat (dokładniej o pionierskich w skali Polski badaniach nad tą odmianą polszczyzny por. Dunaj 2019). Pewną rekompensatą był Wybór... K. Nitscha, a 30 lat później także Polskie teksty gwarowe... Z. Sobierajskiego. Mimo niedostatków w zakresie prezentacji materiału składniowego w swoim czasie były to jedyne zbiory rejestrujące duży zasób polszczyzny mówionej - co prawda gwarowej, ale jednak mówionej.

\section{Wykaz rękopisów}

BAUER J., Zjawiska składniowe w atlasie językowym ogólnosłowiańskim, Archiwum Nauki PAN i PAU w Krakowie, sygn. K III-27, jedn. 11/6.

Klemensiewicz Z., Mat [eriały] warszt[atowe]. Mat[eriały] do składni dialektów, Archiwum Nauki PAN i PAU w Krakowie, sygn. K III-27, jedn. 38.

\section{Literatura}

BAUER J., 1959, Otázka syntaktických jevi̊ v slovanském jazykovém atlase, „Slávia” 28, s. 607-616.

BDP: J. Strutyński (red.), Bibliografia dialektologii polskiej, t. I: Do roku 1975 włacznie, 1981, t. II: Od roku 1976 do roku 1980 włacznie wraz z uzupetnieniami za lata poprzednie, 1986, t. III: Od roku 1981 do 1985 włacznie wraz z uzupetnieniami za lata poprzednie, 1990, Kraków.

Dunaj B., 2019, Badania polszczyzny krakowskiej - przeszłość i teraźniejszość, „LingVaria” nr 1 (27), s. 35-47, [on-line:] https://doi.org/10.12797/LV.14.2019.27.02.

Judycka I., LeWicki A., Iwanowa-Perczyńska N., 1961, Z prac nad kwestionariuszem do badań składni gwar polskich, „Poradnik Językowy” nr 8, s. 371-375.

Kaєкоwsкa A., 2010, Profesor Jadwiga Konieczna-Twardzikowa (1 I 1932-21 IX 2009), „Język Polski” XC, s. 49-56.

Klemensiewicz Z., 1924, O niektórych osobliwościach języka Wyspiańskiego, „Język Polski” XII, s. 6-15.

KLEMENSIEWICZ Z., 1936, Język polski. Wybór wiadomości o znaczeniu i użyciu form językowych oraz o gwarach ludowych dla kl. 4 gimn., Lwów.

KLemensiewicz Z., 1937, Składnia opisowa wspótczesnej polszczyzny kulturalnej, Kraków.

KLemensiewicz Z., 1938a, Osobliwsze funkcje syntaktyczne wyrazu co w gwarach ludowych, „Sprawozdania z Czynności i Posiedzeń Polskiej Akademii Umiejętności” XLIII, nr 5, s. 146-148.

KLemensiewicz Z., 1938b, Wyrażenia przyimkowe $z$ ku, „Sprawozdania z Czynności i Posiedzeń Polskiej Akademii Umiejętności” XLIII, nr 9, s. 273-275.

KLemensiewicz Z., 1946, O wyrazie jak $z$ funkcja wskaźnika zespolenia zdań złożonych $w$ gwarach ludowych, [w:] Inter arma. Zbiór prac ofiarowanych prof. Kazimierzowi 
Nitschowi w siedemdziesiąta rocznicę urodzin (1 II 1944) przez przyjaciót, kolegów i uczniów, Kraków, s. 5-11.

Klemensiewicz Z., 1953, O różnych odmianach współczesnej polszczyzny. Próba charakterystyki odmian współczesnej polszczyzny z uwzględnieniem przypuszczalnych warunków ich poczatkowego rozwoju, Warszawa.

KLemensiewiCz Z., 1957, Język ogólnonarodowy i gwara, „Życie Szkoły” XII, nr 6, s. 91-92.

Klemensiewicz Z., 1958, Swoiste właściwości języka Wyspiańskiego i jego utworów, „Pamiętnik Literacki” XLIX, z. 2, s. 425-504.

Klemensiewicz Z., 1961, Historia jezzka polskiego, cz. 1: Doba staropolska, Warszawa.

Klemensiewicz Z., 1965, Historia języka polskiego, cz. 2: Doba średniopolska, Warszawa.

Klemensiewicz Z., 1966, Niektóre właściwości syntaktyczne chłopskiej mowy potocznej, „Język Polski” XLVI, s. 245-255.

Klemensiewicz Z., 1970, Kilka spostrzeżeń językoznawcy o języku poezji Marii Konopnickiej, „Prace Filologiczne” XX, s. 337-341.

Klemensiewicz Z., 1972, Historia języka polskiego, cz. 3: Doba nowopolska, Warszawa.

Lавосна J., 1996, Problemy składni gwarowej na przykładzie tekstów z Zaolzia, [w:] B. Dunaj, J. Reichan (red.), Studia dialektologiczne I, Kraków, s. 237-242.

Laвосна J., 2018, Składnia gwarowa w badaniach językoznawczych, [w:] R. Przybylska, M. Rak, A. Kwaśnicka-Janowicz (red.), Historia języka, dialektologia i onomastyka w nowych kontekstach interpretacyjnych, Kraków, s. 211-217.

Niтsch K., 1929, Wybór polskich tekstów gwarowych, Lwów.

OLA: Ogólnosłowiański atlas językowy - Obŝčeslavânskij lingvističeskij atlas; dotychczas ukazały się:

w serii fonetyczno-gramatycznej:

t. 1: B. Vidoeski, P. Ivić (red.), sekr. S. Remetić, Refleksy *ě, Belgrad 1988;

t. 2a: V.V. Ivanov, T.I. Vendina, L.E. Kalnyn’ (red.), Refleksy ${ }^{\star} e$, Moskwa 1990;

t. 2b: J. Basara (red.), sekr. A. Basara, H. Zduńska, Refleksy ${ }^{\star}$, Wrocław 1990;

t. 3: J. Basara (red.), sekr. A. Basara, Refleksy ${ }^{{ }} b r,{ }^{{ }^{*}} \mathfrak{b r},{ }^{{ }} b l,{ }^{\star} b l$, Warszawa 1994;

t. 4a: D. Brozović (red.), zast. M. Menac-Mihalić, Refleksy ${ }^{\star}$ b, ${ }^{\star} b$, Zagreb 2006;

t. 4b: Z. Topolińska, D. Petrović (red.), Refleksy ${ }^{*}$ z, ${ }^{*}$ b. Wokalizm sekundarny, Skopje 2003;

t. 5: T.I. Vendina, L.E. Kalnyn' (red.), Refleksy ${ }^{\star}$ o, Moskwa 2008;

t. 6: T.I. Vendina, L.E. Kalnyn’ (red.), Refleksy ${ }^{\star} e$, Moskwa 2011;

w serii leksykalno-słowotwórczej:

t. 1: R.I. Avanesov, V.V. Ivanov (red.), Świat zwierzęcy, Moskwa 1988;

t. 2: B. Falińska, J. Siatkowski (red.), sekr. A. Kowalska, Hodowla zwierząt, Warszawa 2000;

t. 3: A.I. Podłużnyj, A.A. Kryvicky, L.P. Kuncevič (red.), Świat roślinny, Mińsk 20oo;

t. 4: A. Ferenčikova i in. (red.), Gospodarstwo wiejskie, Bratysława 2012;

t. 6: T.I. Vendina (red.), Gospodarstwo domowe i przygotowanie pokarmów, Moskwa 2007;

t. 8: J. Basara, J. Siatkowski (red.), Zawody i życie społeczne, Warszawa 2003;

t. 9: J. Siatkowski, J. Waniakowa (red.), Człowiek, Kraków 2009;

t. 10: T.I. Vendina (red.), Zwyczaje ludowe, Moskwa 2015.

PERCZYŃsKA N., 1962, Badania składni gwar polskich na podstawie próbnego, warszawskiego kwestionariusza syntaktologicznego, [w:] Otázky slovanské syntaxe. Sborník brněnské syntaktické konference, 17.-21.4.1961, Praha, s. 404-406. 
SobIerajSKi Z., 1960-1964, Polskie teksty gwarowe z ilustracją dźwiękowa, t. I-IV, Poznań. Stieber Z., 1958, O projekcie „Ogólnosłowiańskiego atlasu dialektologicznego”, [w:] V.V. Vinogradov (red.), Slavânskaâ filologiâ. Sbornik statej, t. I, Moskva, s. 129-135.

URBAŃCZYK S., 1938, Wartość składniowa polskich tekstów gwarowych, „Sprawozdania z Czynności i Posiedzeń Polskiej Akademii Umiejętności” XLIII, nr 9, s. 146-148.

URbańczy K S., 1959, Międzynarodowa konferencja słowiańskich dialektologów w Warszawie, „Język Polski” XXXIX, s. 390-392.

VoprosniK: Voprosnik obŝeslovânskogo lingvističeskogo atlasa, Moskva 1965.

\section{Zenon Klemensiewicz and the Syntax of Polish and Slavic Dialects Summary}

The paper discusses two issues: 1) Z. Klemensiewicz's previously unknown research in the area of dialectal syntax, and 2) his dispute with J. Bauer, regarding the inclusion of syntax in Ogólnosłowiański atlas jezzykowy ('General Slavic linguistic atlas'). It has transpired that the collections of the Archive of Science of PAN and PAU in Cracow contain Klemensiewicz's materials for Zarys składni polskich dialektów ('An outline of the syntax of Polish dialects'), excerpted from K. Nitsch's Wybór polskich tekstów gwarowych ('A selection of Polish dialectal texts'), as well as the manuscript of the polemic with Bauer's proposal. It seems probable that, by describing the syntax of Polish dialects, Klemensiewicz wanted to capture the characteristics of the syntax of spoken Polish. 